\title{
Regulation of human RPS14 transcription by intronic antisense RNAs and ribosomal protein $\mathrm{S14}$
}

\author{
Elena S. Tasheva and Donald J. Roufa ${ }^{1}$ \\ Division of Biology and Center for Basic Cancer Research, Kansas State University, Manhattan, Kansas 66506-4901 USA
}

\begin{abstract}
RNase protection studies reveal two stable RNAs (250 and 280 nucleotides) transcribed from the antisense strand of the human ribosomal protein gene RPS14's first intron. These transcripts, designated $\alpha-250$ and $\alpha-280$, map to overlapping segments of the intron's 5 ' sequence. Neither RNA encodes a polypeptide sequence, and both are expressed in all human cells and tissues examined. Although $\alpha-280$ is detected among both the cells' nuclear and cytoplasmic RNAs, the great majority of $\alpha-250$ is found in the cytoplasmic subcellular compartment. As judged by its resistance to high concentrations of $\alpha$-amanitin, cell-free transcription of $\alpha-250$ and $\alpha-280$ appears to involve RNA polymerase $I$. Tissue culture transfection and cell-free transcription experiments demonstrate that $\alpha-250$ and $\alpha-280$ stimulate S14 mRNA transcription, whereas free ribosomal protein $\mathrm{S14}$ inhibits it. Electrophoretic mobility shift experiments indicate specific binary molecular interactions between r-protein S14, its message and the antisense RNAs. In light of these data, we propose a model for fine regulation of human RPS14 transcription that involves RPS14 intron 1 antisense RNAs as positive effectors and $\$ 14$ protein as a negative effector.
\end{abstract}

[Key Words: Ribosomal protein; human; RPS14; antisense RNA; autoregulation; transcriptional regulation] Received November 13, 1994; revised version accepted December 14, 1994.

Ribosomal protein (r-protein) gene expression is coordinated with cellular metabolism in bacteria through autoregulatory mechanisms that operate at the levels of transcription (Lindahl et al. 1990; Skouv et al. 1990; Zengel and Lindahl 1990), mRNA processing (Fallon et al. 1979; Mackie 1991), and protein biosynthesis (Nomura et al. 1980; Yates and Nomura 1980; Yates et al. 1980; Cole and Nomura 1986; Kearney and Nomura 1987; Thomas et al. 1987; Mattheakis et al. 1989; Portier et al. 1990; Wikström et al. 1992). Yeast strains employ a similar set of control mechanisms to regulate r-protein gene expression during (Della Sita et al. 1990; Mager and Planta 1990, 1991; Moehle and Hinnebusch 1991; Presutti et al. 1991; Papciak and Pearson 1992/ and after (Gorenstein and Warner 1976; Kief and Warner 1981; Pearson et al. 1982; Warner et al. 1985; Dabeva and Warner 1993) transcription. In contrast, higher animal cells appear to modulate of $r$-protein gene expression primarily at the level of translation (Meyuhas et al. 1987; Hammond and Bowman 1988; Perry and Meyuhas 1990; Levy et al. 1991; Aloni et al. 1992). Nonetheless, several reports indicate that cultured cells from metazoan animals up- or down-regulate transcription of r-protein genes when induced to differentiate (Agrawal and Bowman 1987; Ferrari et al. 1990; Mailhammer et al. 1992),

${ }^{1}$ Corresponding author. as a result of neoplastic transformation (Pogue-Geile et al. 1991; Henry et al. 1993), and in response to unusual genetic selections in tissue culture (Laine et al. 1991; $\mathrm{Li}$ and Center 1992). Thus, despite experiments that demonstrate constitutive expression of mammalian r-protein genes in exponentially growing tissue culture cells (Rhoads and Roufa 1987), these observations indicate that under special physiological and tissue culture circumstances, mammalian r-protein genes are regulated dynamically at the level of transcription.

To elucidate the molecular mechanisms that regulate transcription of mammalian r-protein genes, it is necessary to examine the genes using state-of-the-art biochemical and genetic approaches. The human RPS14 locus encodes ribosomal protein S14 and is especially well suited for these studies. It is the only mammalian r-protein locus in which a drug selection system facilitates somatic genetics (Boersma et al. 1979; Madjar et al. 1982, 1983; Diaz et al. 1990; Diaz and Roufa 1992; Tasheva and Roufa 1993) and for which both genomic and cDNA clones carrying numerous wild-type and mutant alleles are available (Rhoads et al. 1986; Rhoads and Roufa 1987; Diaz et al. 1990; Overman et al. 1993).

We have shown previously that expression of human RPS14 minigenes in cultured rodent cells requires at least 32 bp of proximal upstream DNA, the gene's 55-bp noncoding first exon, and a short $(<300 \mathrm{bp})$ segment of its first intron (Rhoads et al. 1986; Rhoads and Roufa 
1987). DNA footprinting and electrophoretic mobility shift assays (EMSAs) of RPS14 minigenes carrying chemically defined deletion, insertion, and base substitution mutations indicated that RPS14 carries cis-active DNA regulatory motifs located both up- and downstream of its mRNA initiation site (Overman et al. 1993). The upstream regulatory elements consist of at least the pair of similar DNA sequences $\left(5^{\prime}\right.$-CCGGAAR-3') that cooperatively bind transcription factor E2F (see Fig. 1). The gene's downstream regulatory elements include a 10 -bp binding site for a transcription factor designated NF- $\beta 1$ (Fig. 1). Although large deletion mutations surrounding the NF- $\beta$ l-binding site (such as between the BamHI and $S m a I$ sites illustrated in Fig. 1) abrogated S14 transcription completely, site-specific deletions within the $\beta 1$ protein-binding site reduced transcription only partially (Overman et al. 1993). For this reason, we proposed that the RPS14 downstream regulatory array is likely to be composed of multiple, cis-active functional elements, only one of which (the $\beta 1$-binding site) is detected by electrophoretic methods used conventionally to assess DNA-protein interactions.

One intriguing possibility is that the RPS14 downstream promoter domain also might encode a regulatory RNA important for optimal gene expression. The intervening and flanking segments of several eukaryotic loci are known to code for putative regulatory RNAs (Belhumeur et al. 1988; Kimelman and Kirshner 1989; Krystal et al. 1990; Hildebrandt and Nellen 1992; Spicer and Sonenshein 1992; Khochbin and Lawrence 1994). For example, snRNAs U16 and Ul8 are processed from the transcribed intron sequences of mammalian and amphibian r-protein Ll mRNA precursors (Prislei et al. 1993), and snRNA U15A is excised from human RPS3 intron 1 pre-mRNA transcripts (Tycowski et al. 1993). Similarly, murine c-myc (Nepveu and Marcu 1986) and p53 (Khochbin and Lawrence 1994) genes encode overlapping antisense RNAs that are thought to regulate the expression of those genes. A cryptic promoter within c-myc's second intron governs transcription of the lymphoma-specific, translocated c-myc/immunoglobulin constant chain fusion gene expressed by plasmacytoma cell lines (Spicer and Sonenshein 1992); and a stable 1.3$\mathrm{kb}$ antisense RNA is transcribed from p53's first intron when p53 is down-regulated during murine erythroleukemia (MEL) cell differentiation (Khochbin and Lawrence 1994).

To ascertain whether human RPS14 intron 1 encodes a regulatory RNA, we examined the transcripts synthesized by several human cell lines and primary tissues using an RNase protection assay /Gibbs and Caskey 1987). Previously, we had reported that full-length S14 mRNA is the only transcript initiated from the sense strand of this human chromosome segment (Rhoads and Roufa 1987; Overman et al. 1993). Therefore, our cuŕrent experiments focused on a search for antisense RNAs that might derive from the RPS14 regulatory intron. This survey indicated that RPS14 intron 1 codes for a pair of stable, overlapping antisense transcripts, designated $\alpha-250$ and $\alpha-280$, whose sequences contain the NF- $\beta 1$ protein-binding site. Both antisense transcripts also are synthesized in cell-free reactions that contain cloned RPS14 DNA templates and a crude HeLa cell nuclear protein extract. This reaction is resistant to high concentrations of $\alpha$-amanitin $(300 \mu \mathrm{g} / \mathrm{ml})$, suggesting that it is catalyzed by an $\alpha$-amanitin-resistant RNA polymerase, perhaps RNA polymerase I. Transient expression tissue culture assays and the cell-free reaction were used to investigate the effects of $\alpha-250 / \alpha-280$ and free r-protein S14 on transcription of human S14 mRNA. Much to our surprise, we observed that $\alpha-250$ and $\alpha-280$ specifically stimulated synthesis of human S14 message, whereas excess free S14 protein repressed RPS14 mRNA transcription. Electrophoretic experiments revealed stable binary interactions among human r-protein S14, the antisense RNAs, and S14 message. Based on these observations, we propose a model for fine regulation of human RPS14 mRNA transcription in which $\alpha-250$ and $\alpha-280$ are positive effectors and free $\mathrm{S} 14$ protein is a negative effector.

\section{Results}

Identification of antisense RNAs encoded by RPS14 intron 1

To examine human cells for stable antisense RNAs encoded by the regulatory portion of RPS14 intron 1, total cellular RNA was purified from cultured male fibrosarcoma cells (HT1080). The RNA was screened by RNase $A+T 1$ protection using a uniformly labeled sense strand ${ }^{32}$ P-labeled RNA probe transcribed from the plasmid clone pGANB (Fig. 1A). As indicated in Figure 1A, pGANB carries the entire $5^{\prime}$ end of human RPS14, including upstream flanking DNA, exon I, intron 1, and the first $60 \mathrm{bp}$ of exon II. This probe detected two antisense RNAs (250 and 280 nucleotides, Fig. 2, lane a) that were designated $\alpha-250$ and $\alpha-280$, respectively.

To map $\alpha-250$ and $\alpha-280$ within the pGANB RPS14 DNA sequence, we performed ribonuclease protection analyses using sense strand ${ }^{32} \mathrm{P}$-labeled RNA probes transcribed from the other plasmid clones illustrated in Figure 1A. Two probes were synthesized fro $\mathrm{m}$ plasmid pGA4 as PfIMI and NcoI runoff transcripts. These RNAs, which included the BspmI-PfIMI and BspMI-Ncol segments of RPS14 intron 1, also detected $\alpha-250$ and $\alpha-280$ (Fig. 2A, lanes b and $c$, respectively). This indicated that both antisense RNA sequences are encoded totally within RPS14 intron 1 . In contrast, a probe transcribed from plasmid pG50, which terminates at the intron 1 BamHI site, detected only a single band of antisense RNA (128 nucleotides, Fig. 2A, lane d, and B, lane a). This suggested that $\alpha-250$ and $\alpha-280$ share a common $3^{\prime}$ end located 128 nucleotides to the left of the intron 1 BamHI site (labeled B in Fig. 1A). Based on the antisense RNAs' molecular lengths, we positioned their $5^{\prime}$ ends $122(\alpha-250)$ and 152 bp $(\alpha-280)$ to the right of the BamHI cleavage site. To confirm these assignments, we constructed pGTOI, a plasmid clone that harbors a 291-bp PCR-amplified fragment of intron 1 DNA /residues 300- 
Figure 1. (A) Restriction map of the 4-kb NarI-HindIII DNA fragment cloned as the human RPS14 minigene pCS14-83. The diagram (not to scale) illustrates the relative locations and transcriptional orientations of antisense RNAs $\alpha-250$ and $\alpha-280$ (thick arrows). Dark rectangles (I and II-V) represent minigene exons. DNA sequences contained by several other plasmid subclones are marked by horizontal lines below the restriction map. A detailed description of these DNAs is contained in Materials and methods. Restriction endonuclease cleavage sites identified are (N) NarI; (E) EcoRI; (Bs) BspMI; (B) BamHI; (Nc) NcoI; (Pf) PfIMI; (Bu) Bsu36I; (A) AvaI; and (H) HindIII. DNA sites that bind nuclear proteins $E 2 F$ and NF- $\beta 1$ are indicated above the map. (B) Antisense DNA sequence at the $5^{\prime}$ end of human RPS14. Nucleotide positions are numbered in accord with the index used in GenBank laccession no. M13934). The $\alpha-280$ and $\alpha-250$ transcriptional initiation sites are represented by
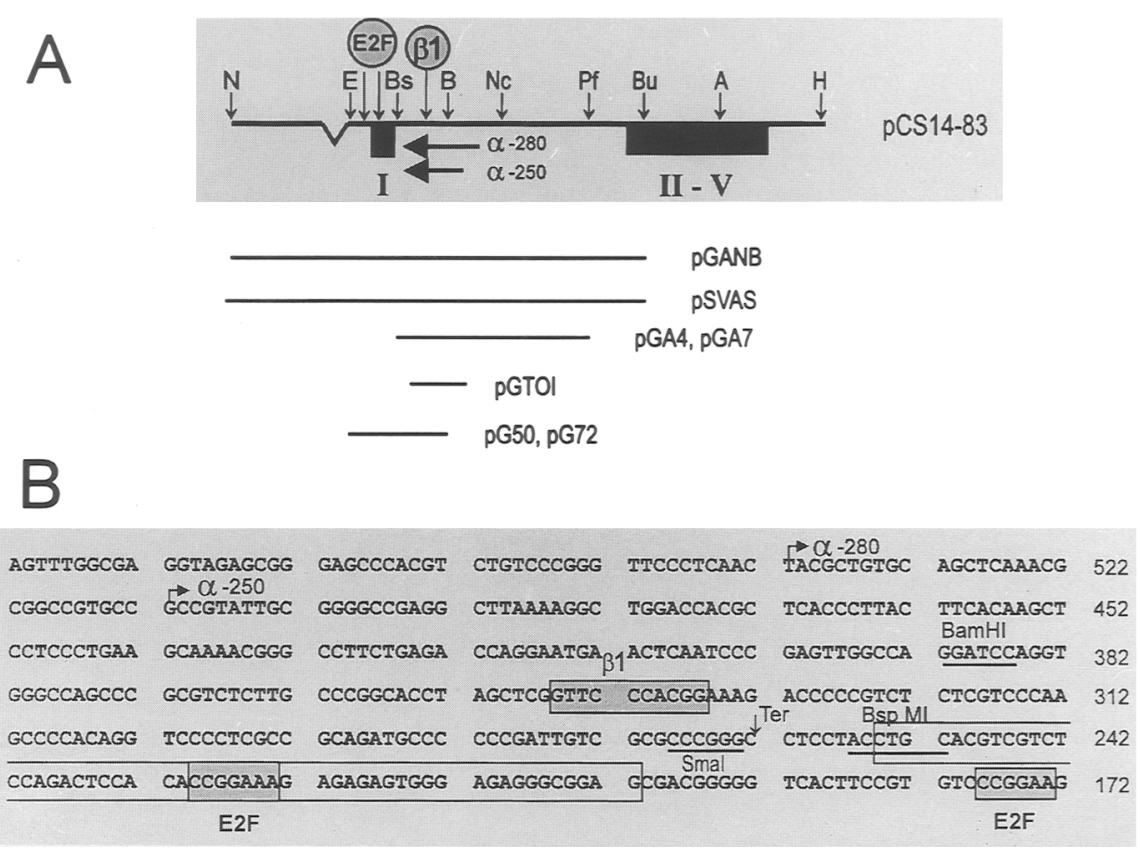
arrows, and their common termination site is labeled Ter. Cleavage sites for restriction endonucleases BamHI, BspMI, and $S m a \mathrm{I}$ are underlined. The open rectangle delineates the boundaries of exon $\mathrm{I}$; shaded rectangles indicate protein-binding motifs (E2F and NF- $\beta 1$ ) known to reside within the sequence. See text for details.

590, Fig. 1B). This clone lacks 39 bp of the DNA thought to encode the $3^{\prime}$ ends of $\alpha-250$ and $\alpha-280$. As expected, the riboprobe transcribed from pGTOI detected a pair of antisense RNA bands 211 and 241 nucleotides long (Fig. 2A, lane e, and B, lane b), 39 nucleotides shorter than comparable RNA as revealed with the full-length pGANB and pGA4 probes. The mapping data illustrated in Figure 2 are summarized in Figure $1 \mathrm{~A}$ and by an annotated nucleotide sequence in Figure 1B. As indicated, $\alpha-250$ and $\alpha-280$ share a common $3^{\prime}$ end at position 262 , 8 nucleotides downstream of RPS14 exon I. Their $5^{\prime}$ ends reside between the unique $B a m H I$ and $N c o$ I cleavage sites (Fig. 1A) at positions 511 for $\alpha-250$ and 541 for $\alpha-280$ (Fig. 1B). The DNA sequence coding for both antisense RNAs overlaps the 10 -bp binding site determined previously for transcription factor NF- $\beta 1$ (Overman et al. 1993).

\section{Subcellular distribution of $\alpha-250$ and $\alpha-280$}

If the RPS14 intron 1 antisense RNAs regulate S14 transcription, we expect them to reside near the cell's transcriptional machinery, that is, within the nucleus. Therefore, nuclear and cytoplasmic RNAs were prepared from HT 1080 cells, and the fractionated RNAs were examined by RNase protection. As illustrated in Figure 3A, $\alpha-250$ and $\alpha-280$ both were detected in HT1080 nuclear and cytoplasmic RNAs. $\alpha-250$ was the predominant species in the cytoplasm (Fig. 3A, lanes a,b); and $\alpha-280$ was the major species in the nucleus (Fig. 3A, lanes c,d). When corrected for total RNA yields on a per cell basis, densitometric analysis of the data in Figure $3 \mathrm{~A}$ indicated that $\alpha-280$ distributes approximately equally between the cells' nucleus and cytoplasm, whereas $>90 \%$ of the cell's $\alpha-250$ was obtained from cytoplasmic RNA.

To determine whether $\alpha-250$ and $\alpha-280$ are detected in a variety of human cells and tissues, total cell RNAs were purified from three other human cell lines and assayed for RPS14 intron 1 antisense transcripts. As illustrated in Figure 3B, female HeLa cervical carcinoma cells (lane a), CCRF-CEM acute T-lymphoblastic leukemia cells (lane b), and HL-60 promyeloblastic leukemia cells (lane c) all elaborate $\alpha-250$ and $\alpha-280$. Similarly, total cell RNA preparations from several primary human tissues were assayed for RPS14 intron 1 antisense RNAs (Fig. 3C). $\alpha-250$ and $\alpha-280$ were detected in human brain (lane a), liver (lane b), lung (lane c), placenta (lane d), and kidney (lane e) RNAs.

\section{Cell-free transcription of $\alpha-250$ and $\alpha-280$ is resistant to $\alpha$-amanitin}

To characterize antisense transcription within the upstream portion of human RPS14 intron 1, we optimized a cell-free reaction system that synthesizes biologically accurate RNAs in response to cloned DNA templates (Spicer and Sonenshein 1992). As indicated by data illustrated in Figure 4 (lane b), a long sense strand transcript encoding S14 pre-mRNA, as well as the antisense RNAs $\alpha-250$ and $\alpha-280$, is synthesized in reactions that contain a DNA template encoding the entire human RPS14 locus and $\left[\alpha-{ }^{32} \mathrm{P}\right] \mathrm{rUTP}$. These data also demonstrate that cellfree transcription depends completely on addition of the duplex DNA template (Fig. 4, lane b vs. a) and that the molecular sizes of $\alpha-250$ and $\alpha-280$ were not affected by ribonuclease digestion in the experiments illustrated in 

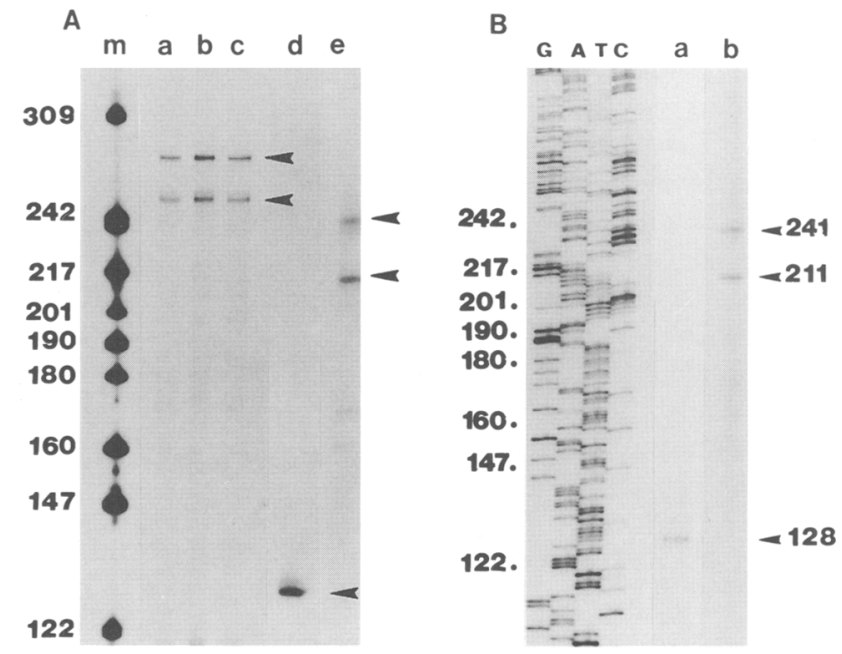

Figure 2. The $\alpha-250$ and $\alpha-280$ transcription units map to the $5^{\prime}$ end of RPS14 intron 1. (A) Labeled RNA probes were incubated with total RNA from HT1080 cells, and RNase protection analyses were performed. Nuclease-resistant fragments were separated by electrophoresis through $8 \%$ denaturing polyacrylamide gels. The uniformly ${ }^{32} \mathrm{P}$-labeled sense RNA probes used were full-length HindIII runoff transcripts of pGA4 (lane $a$ ) and pGANB (lane $b$ ), an NcoI runoff transcript of pGA4 (lane $c$ ), and full-length HindIII runoff transcripts of pG50 (lane $d$ ) and pGTOI (lane $e$ ). End-labeled HpaII DNA fragments of pBR322 were used as molecular size markers (lane $m$ ). Their sizes (in bp) are indicated at left. Arrows to the right of lanes $c, d$, and $e$ mark the protected RNA fragments discussed in the text. $(B)$ HT-1080 RNA was analyzed by ribonuclcase protection using a HindIII runoff transcript of pG50 (lane $a$ ) and pGTOI (lane $b$ ). The nuclease-resistant riboprobe fragments were analyzed by electrophoresis through an $8 \%$ buffer gradient sequencing gel with molecular weight markers that consisted of pBR322 HpaII DNA fragments (indicated by dots at left) and a DNA sequence ladder (lanes $G, A, T, C$ ).

Figures 2 and 3 . That is, $\alpha-250$ and $\alpha-280$ appear to be full-length antisense transcripts rather than fragments (exons?) of a longer RNA.

To analyze cell-free transcription of human RPS14 intron 1 further, we used plasmid pGANB (Fig. 1) as a run- off transcription template. pGANB includes all of the sequences necessary for accurate transient expression of S14 mRNA in cultured rodent cells (Rhoads and Roufa 1987; Overman et al. 1993/ and, based on the data in Figure 2, also should encode $\alpha-250$ and $\alpha-280$. Both sense and antisense transcripts synthesized in vitro were assayed by nuclease protection using complementary RNA probes.

In the electrophoretograms shown in Figure 5, lanes $a-h$, contained cell-free reaction products directed by pGANB template. Samples analyzed using a pGANB probe for antisense RNAs (lanes a-d) demonstrate that the cell-free reaction accurately transcribed $\alpha-250$ and $\alpha-280$ in approximately equal amounts (lane a). Surprisingly, cell-free transcription of antisense RNA was resistant to high concentrations of $\alpha$-amanitin (lanes b, c, and d), suggesting that the antisense RNAs are not synthesized by human RNA polymerase II in vitro. $\alpha$-Amanitin at 200 (lane c) and $300 \mu \mathrm{g} / \mathrm{ml}$ (lane d) had little to no effect on the amounts of antisense RNA transcribed. S14 mRNA exons (i.e., sense strand runoff products) also were detected in the cell-free reactions (lane e). However, as expected for RNA polymerase II transcripts, synthesis of these RNAs was completely inhibited by low concentrations of $\alpha$-amanitin (lanes $f-h$ ). The lack of detectable RNA products in reactions directed by vector pGEM-1 DNA without a human gene insert attests to the cell-free system's requirement for an authentic mammalian transcriptional template (lanes $\mathbf{i}-\mathbf{j}$ ). Furthermore, another human r-protein minigene, pCS17-92 (C.G. Maki and D.J. Roufa, unpubl.), also was faithfully transcribed in vitro to yield the expected $r$-protein $\$ 17$ mRNA runoff product (lane $\mathrm{k}$ ), whose synthesis was sensitive to $\alpha$-amanitin (lanes $1-\mathrm{n}$ ).

\section{Overexpression of $\alpha-250$ and $\alpha$-280 stimulates $S 14$ $m R N A$ transcription in vivo and in vitro}

The RPS14 antisense transcripts described above exhibit at least three characteristics expected for RNAs that might regulate human $\mathrm{r}$-protein mRNA transcription: (1) They map to the region of RPS14 intron 1 necessary for expression of S14 transgenes (Rhoads and Roufa 1987;

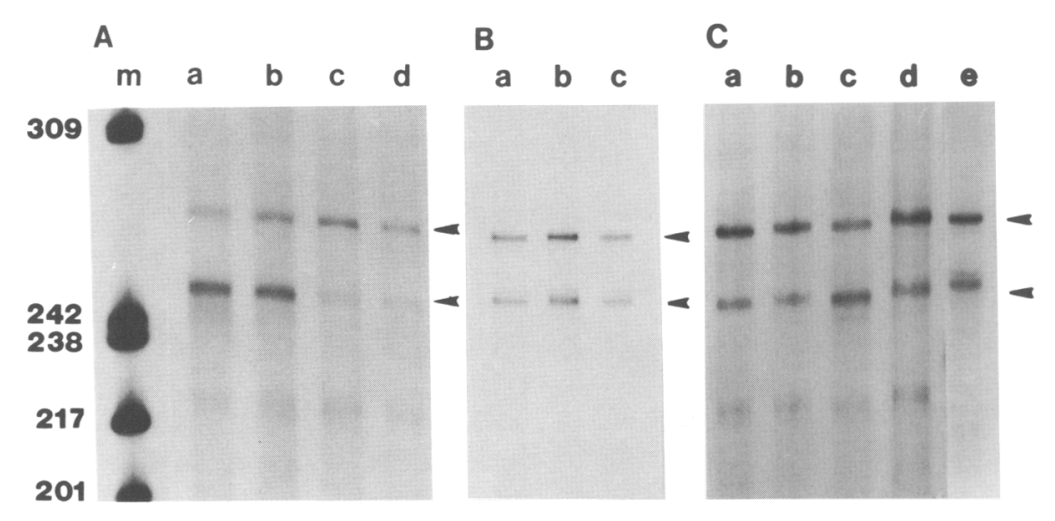

Figure 3. (A) Distribution of antisense RNAs $\alpha-250$ and $\alpha-280$. Cytoplasmic $\{$ lanes $a, b\rangle$ and nuclear (lanes $c, d$ ) RNAs were purified as described in Materials and methods. RNase protection analyses were carried out with uniformly labeled ${ }^{32} \mathrm{P}$-labeled RNA probe transcribed from pGA4 as an NcoI runoff RNA. Other details are described in the legend to Fig. 2. (B) Total cellular RNA was isolated from HeLa S3 cells (lane a), CCRF-CEM cells (lane $b$ ), and HL-60 cells (lane $c$ ). All three samples were analyzed by RNase protection as described above. (C) RNAs purified from human brain (lane $a$ ), liver (lane $b$ ), lung (lane $c$ ), placenta (lane $d$ ), and kidney (lane $e$ ) were examined for S14 intron I antisense RNAs as above. 


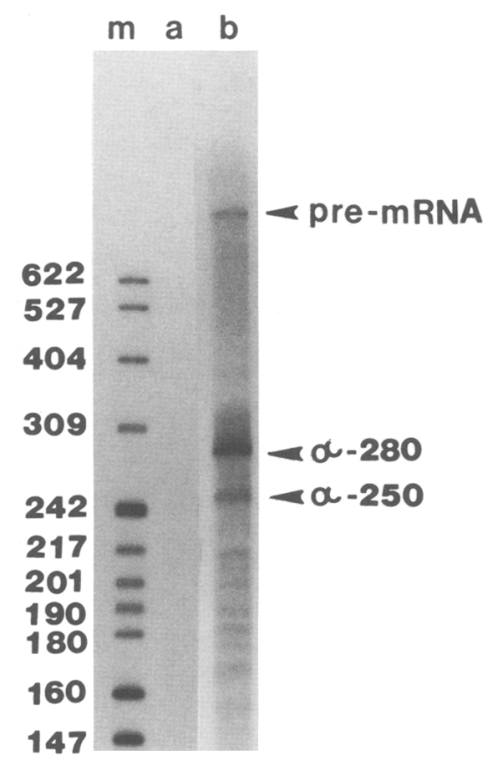

Figure 4. A $12.5-\mathrm{kb}$ HindIII fragment of human RPS14 chromosomal DNA was excised from bacteriophage $\lambda$ clone HGS14-1 (Rhoads et al. 1986) and used as the DNA template in a cell-free transcription reaction that contained ${ }^{32} \mathrm{P}$ ]rUTP. (Details of the reaction conditions are contained in Materials and methods.) The radioactive RNAs transcribed in vitro were purified and analyzed without RNase digestion by denaturing polyacrylamide gel electrophoresis. When the DNA template was omitted from the reaction mixture, no radioactive RNA products were synthesized (lane $a$ ). End-labeled pBR.322 HpaII DNA fragments were used as molecular size markers (lane $m$ ). Three major RNAs were synthesized in vitro. The largest (labeled pre-mRNA) is a sense-strand transcript encoding r-protein S14. The two shorter RNAs (labeled $\alpha-250$ and $\alpha-280$ ) are the same antisense transcripts observed in living cells /Figs. 2 and 3).

Overman et al. 1993); (2) most of the $\alpha-280$ detected in human cells is located in the nucleus at the site of mRNA transcription; and (3) they are expressed at comparable levels in diverse human cell lines and primary tissues. Therefore, we decided to determine whether $\alpha-250$ and $\alpha-280$ directly affect S14 mRNA transcription in cultured human cells and in the cell-free reaction described above.

To conduct the test in cultured cells, the expression clone pSVAS (Fig. 1) was assembled by introducing the pGANB NarI-HindIII DNA fragment into pSV2Neo (Southern and Berg 1982), where its transcription is ensured by its own promoter as well as the SV40 early promoter. Because the antisense RNAs encoded by pGANB are correctly terminated in vitro (Fig. 5), we anticipated that pSVAS contains all of the information necessary to express full-length antisense RNAs in vivo. pSVAS DNA was introduced into human HT1080 cells by lipofectamine-mediated transfection. Twenty-four hours later, total cell RNAs were prepared from transfected as well as nontransfected control cells for analysis by nuclease protection.
As shown in Figure 6A, RNA purified from transfected cells contained approximately fivefold higher levels of $\alpha-250$ and $\alpha-280$ (lane a) than RNA from control cells (lane b). This was accompanied by a comparable increase in the intracellular level of S14 mRNA in transfected (lane c) over control (lane d) cells. In contrast, overexpression of the antisense RNAs did not affect the level of r-protein S24 message in transfected cells (lane e) as compared with nontransfected control cells (lane f). These data indicated that elevated expression of $\alpha-250$ and $\alpha-280$ results in the locus-specific stimulation of $\mathrm{S} 14$ mRNA synthesis in cultured HT1080 cells.

The stimulatory effect of transgenic antisense RNA on RPS14 mRNA transcription in cultured human cells suggests that $\alpha-250$ and $\alpha-280$ is able to affect S14 message synthesis in the trans configuration. That is, stimulation

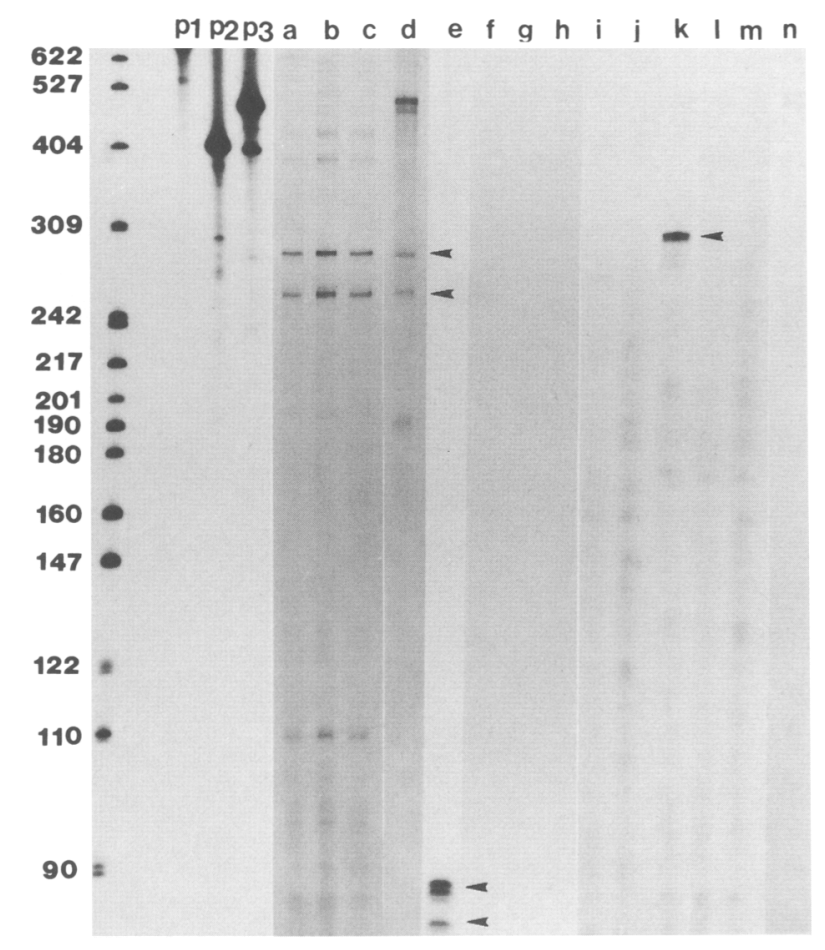

Figure 5. Cell-free runoff synthesis of RPS14 sense and antisense transcripts. RNAs were synthesized in vitro from pGANB (lanes $a-h$ ) or pGEM-1 (lanes $i-i$ ) DNA templates as HindIII runoff products or from supercoiled pCS17-92 DNA, which encodes a 320-bp fragment of human S17 mRNA (lanes $k-n)$. Transcription products were assayed by RNase protection using uniformly labeled probes that detected S14 antisense RNA (lanes $a-d, i)$, sense-strand S14 mRNA (lanes $e-h, i)$ and sense-strand S17 mRNA (lanes $k-n$ ). Arrows to the right of lanes $d, e$, and $k$ mark the protected RNA bands discussed in the text. Lanes $b-d, f-h$, and $l-n$ were loaded with RNA transcribed in reactions containing $\alpha$-amanitin $(1,200$, and $300 \mu \mathrm{g} / \mathrm{ml}$, respectively|. Lanes $p 1-p 3$ contained the intact radioactive probes used to detect antisense S14 RNA, sense-strand S17 mRNA, and sense-strand S14 mRNA. The intense $\sim 500$-nucleotide RNA band detected in lane $d$ was not a reproducible transcription product. Other experimental details are described in the legend to Fig. 2 and Materials and methods. 


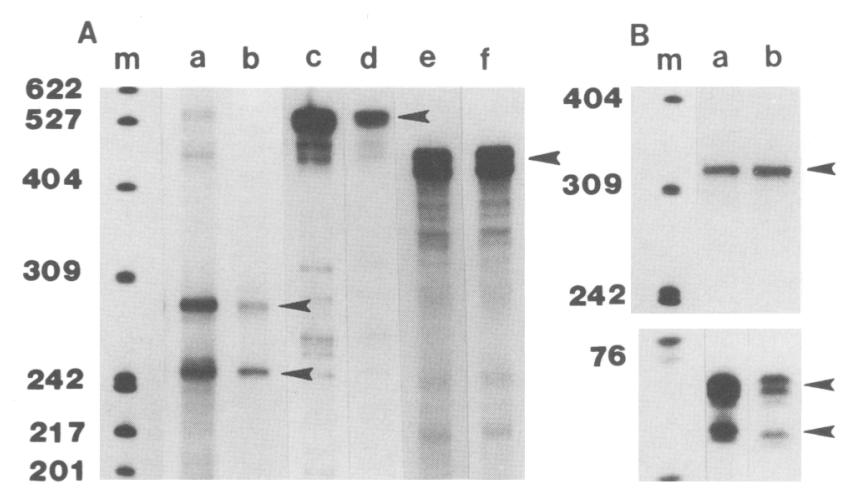

Figure 6. S14 intron 1 antisense RNA stimulates RPS14 message transcription. $|A|$ Transient expression of pSVAS enhances transcription of S14 mRNA in cultured human cells. Total cellular RNAs $(10 \mu \mathrm{g})$ were prepared from HT1080 cells transfected with pSVAS (lanes $a, c, e$ ) or nontransfected control cells (lanes $b, d, f)$. The RNAs were analyzed by ribonuclease protection using probes that detect RPS14 intron 1 antisense transcripts (lanes $a, b$ ), S14 mRNA (lanes $c, d$ ) or RPS24 mRNA (lanes $e, f) .(B)$ RPS14 intron 1 antisense RNA stimulates cell-free transcription of S14 message. (Top) pCS17-92 DNA template was incubated in HeLa cell nuclear extract either with $800 \mathrm{ng}$ (lane $a$ ) or without (lane b) RPS14 intron 1 antisense RNA (see text for details). (Bottom) pGANB DNA template cut with HindIII was incubated in the cell-free transcription reaction either with 800 ng (lane $a$ ) or without (lane b) RPS14 intron 1 antisense RNA. Arrowheads indicate the nuclease-resistant RNA bands discussed in the text.

does not require that $\alpha-250 / \alpha-280$ be transcribed from RPS14 intron 1, nor does it require that they be synthesized in the antisense orientation. Based on these results, it seemed likely that $\alpha-250$ and/or $\alpha-280$ interact directly with the RPS14 promoter and that this interaction might occur in the cell-free transcription reaction described above. Therefore, we prepared an antisense runoff RNA reagent slightly longer than $\alpha-280$ (designated $\alpha-280^{\prime}$ ) from the pGA7 DNA template (Fig. 1A) and studied its effect on the standard RPS14 cell-free transcription reaction. As shown in Figure 6B (bottom), $800 \mathrm{ng}$ of $\alpha-280^{\prime}$ stimulated cell-free synthesis of S14 mRNA two- to threefold (lane a) compared with control reactions that contained only the $\alpha-250$ and $\alpha-280$ transcribed in vitro from the pGANB DNA template (see Fig. 5, lane a). On the other hand, addition of $\alpha-280^{\prime}$ had no discernible effect on mRNA transcription from the RPS17 minigene template, pCS17-92 (Fig. 6B, top).

Two aspects of the data in Figure 6 are particularly noteworthy. (1) Unlike other naturally occurring antisense RNAs, which are thought to negatively regulate gene expression during cellular differentiation and neoplastic transformation (Nepveu and Marcu 1986; Khochbin and Lawrence 1994), $\alpha-250, \alpha-280$, and $\alpha-280^{\prime}$ stimulate S14 mRNA transcription in vivo as well as in vitro; (2) the effect of $\alpha-280^{\prime}$ on cell-free S14 mRNA transcription indicates that the antisense RNA interacts directly with the RPS14 transcription complex.

\section{Overexpression of heterologous $S 14$ protein inhibits} transcription of human S14 mRNA

Autoregulation of gene expression has been demonstrated at several prokaryotic (Yates et al. 1980; Yates and Nomura 1980; Singer and Nomura 1985; Cole and Nomura 1986; Mattheakis et al. 1989; Lindahl and Zengel 1990; Petersen 1990; Portier et al. 1990; Skouv et al. 1990; Zengel and Lindahl 1990; Mackie 1991) and lower eukaryotic (Presutti et al. 1991; Dabeva and Warner 1993) r-protein loci. Mechanisms responsible for autoregulation appear to operate at the levels of transcriptional termination, mRNA processing, and translational initiation. In light of this, we wanted to determine whether free r-protein S14 might have an autoregulatory effect on mRNA transcription at the human RPS14 locus.

To examine this question in cultured human cells, we followed an experimental strategy similar to the one illustrated in Figure 6. A cDNA expression clone of the Drosophila melanogaster RPS14A locus constructed in pSV2Neo, pCS14-93 (Maki et al. 1990), was introduced into human HT1080 cells. The insect S14 clone lacks all introns and, as far as we can tell, does not encode antisense RNAs analogous to $\alpha-250$ and $\alpha-280$. Twentyfour hours later, total cell RNAs were prepared and analyzed by RNase protection. We have shown previously that pCS14-93 is expressed in stably transformed mammalian cells and that it codes for an r-protein that is assembled into functional mammalian ribosomes (Maki et al. 1990). Data in Figure 7A indicated that transient expression of insect S14 also elicited a two- to threefold reduction in the intracellular levels of endogenous human S14 message and RPS14 intron 1 antisense RNAs but had no effect on the levels of r-protein S24 mRNA. Similarly, recombinant glutathione $S$-transferase (GST)S14 fusion protein inhibited cell-free RPS14 mRNA transcription in vitro, whereas recombinant GST protein by itself did not (Fig. 7B).

\section{Human S14 specifically binds to RPS14 intron 1 antisense transcripts and $\$ 14 \mathrm{mRNA}$}

The experiments described above demonstrate that human $\alpha-250 / \alpha-280$ stimulate transcription of human S14 message and that excess, free r-protein S14 (both human and insect) inhibits transcription of RPS14 mRNA and antisense RNAs. Although the effects on S14 RNA transcription were small (two- to fivefold), they were reproducible, locus specific, and observed in both living human cells and cell-free transcription reactions.

To test for binary molecular interactions between $\mathrm{S} 14$ protein and $\alpha-250 / \alpha-280$ that might account for the observed regulatory effects, four series of EMSAs were performed (Fig. 8). In the first set of experiments, a fulllength, ${ }^{32}$ P-labeled RPS14 intron 1 antisense runoff transcript was used as the probe and a crude mixture of HT1080 ribosomal proteins as the source of S14 protein (Fig. 8A). When r-proteins were incubated with the ra- 


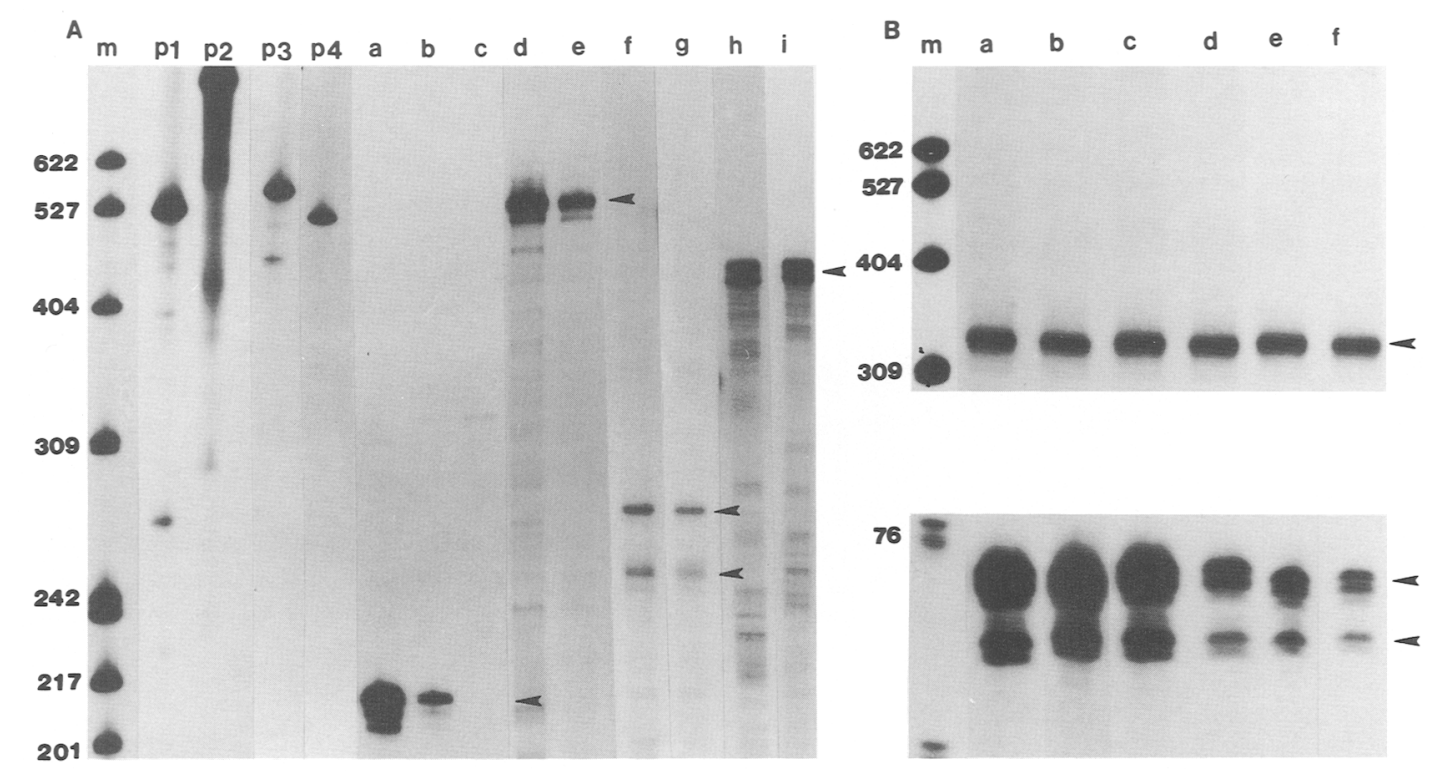

Figure 7. S14 proteins specifically inhibit transcription at the RPS14 locus. (A) Transient expression of an heterologous S14 protein inhibits transcription of both S14 mRNA and intron 1 antisense RNAs in cultured human cells. An RNA probe specific for $D$. melanogaster S14 message was used to detect S14 mRNA in extracts of Drosophila larvae (lane a), HT1080 cells transfected with pCS14-93, a pSV2neo expression vector of the Drosophila RPS14A locus (lane b), and nontransfected HT1080 control cells (lane c). In addition, total cell RNAs from transfected (lanes $e, g, i)$ and control nontransfected (lanes $d, f, h$ ) HT 1080 cells were assayed usi ng RNA probes for human S14 message (lanes $d-e$ ), RPS14 intron 1 antisense RNAs (lanes $f-g$ ), and S24 message (lanes $h-i)$. Lanes p1-p4 contained undigested riboprobes for human S14 antisense RNAs, Drosophila S14 mRNA, human S14 message and human S24 mRNA, respectively. (B) Recombinant human S14 protein specifically inhibits cell-free transcription of human S14 message. (Top) pCS17-92 DNA was used to direct cell-free transcription of a human S17 runoff mRNA fragment (lanes $a-f$ ) in reaction mixtures that also contained 5 (lane $b$ ) or 10 (lane $c$ ) $\mu \mathrm{g}$ of recombinant GST protein or 5 (lane $d$ ), 10 (lane $e$ ), or $15 \mu \mathrm{g}$ (lane $f$ ) of recombinant GST-Sl4 fusion polypeptide. The arrowhead at right indicates the nuclease-resistant, 320-nucleotide runoff product expected from pCS17-92. (Bottom) Template pGANB was used to direct cell-free synthesis of S14 mRNA as a HindIII runoff product (lane a). Because the RNA probe was a transcript of S14 cDNA, mRNA reaction products are detected as two exonic RNA fragments (exon I, 55 nucleotides; exon II, 60 nucleotides). Neither 5 (lane $b$ ) nor $10 \mu \mathrm{g}$ (lane $c$ ) of recombinant GST protein affected S14 mRNA synthesis, but recombinant GST-S14 fusion protein added at concentrations of 5,10 , and $15 \mu \mathrm{g}$ per reaction (lanes $d-f$, respectively) progressively inhibited its transcription.

dioactive probe, a shifted molecular complex (arrowhead) was observed (lane a). The binding of RNA to r-proteins was saturable and specific with respect to RNA sequence, as excess unlabeled antisense RNA competed for the binding of radioactive probe (lanes $b, c$ ) but large amounts of yeast tRNA did not (lane d). R-proteins could not be replaced by bovine serum albumin (BSA) in the binding reaction (lane e), and only the RNA probes that included antisense sequences from the RPS14 intron 1 regulatory region bound the r-protein (lanes $f, g$ ).

In a second series of experiments, an antibody directed against the carboxyl terminus of human $\mathrm{S} 14$ protein was used to demonstrate that $\mathrm{S} 14$ protein is the $\mathrm{r}$-protein that specifically binds antisense RNA probe (Fig. 8B). As in A, a full-length RPS14 intron 1 antisense RNA transcript was used as the ${ }^{32} \mathrm{P}$-labeled probe. When the r-protein/ RNA-binding reaction was postincubated with S14-specific antiserum, a ternary complex composed of the antibody, r-protein, and antisense RNA was observed (upper arrowhead, lane b). However, when the RNA-protein complex was postincubated with preimmune control serum, no ternary complex was detected (lane e). Similarly, no ternary complex was evident among the products of reactions in which either anti serum (lane c) or preimmune serum (lane d) was incubated with the r-protein mixture before addition of radioactive probe. Preincubation of the r-protein mixture with the S14 antiserum resulted in streaking of the specific binary RNA-protein complex (lower arrowhead, lane c), suggesting that S14 antibody destabilized the antisense RNA/r-protein binary interaction.

In a third series of experiments, the radioactive probe was replaced by shorter antisense runoff transcripts, one of which carries a site-specific, 34-bp deletion surrounding the NF- $\beta 1$ footprinted motif (residues 361-328, Fig. 1B). As shown in Figure 8C, human $\mathrm{S} 14$ bound to the shorter wild-type RNA (lane a) but did not associate with the deletion RNA (lane b).

Finally, a fourth series of experiments demonstrated that recombinant $\mathrm{S} 14$ protein, purified as a GST fusion polypeptide, specifically bound to RPS14 intron 1 antisense RNA (Fig. 8D). As shown, a binary RNA-protein complex was detected when the mixture of human r-proteins was replaced by GST-S14 fusion polypeptide (lane 

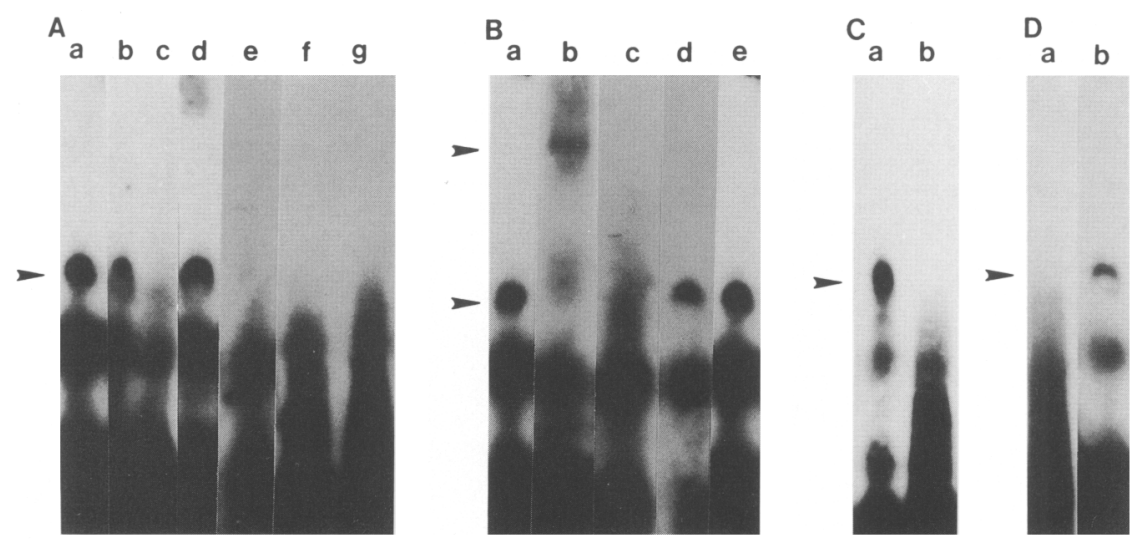

Figure 8. R-protein S14 binds specifically to RPS14 intron 1 antisense RNA. (A) Fulllength, antisense ${ }^{32} \mathrm{P}$-labeled RNA probe transcribed from the pGA7 DNA binds to a mixture of purified human r-proteins (lane a). When the binding reactions also contained a 10- (lane $b$ ) or 100-fold (lane $c$ ) excess of unlabeled antisense competitor RNA, intensities of the complex band decreased. However, when a 100-fold excess of yeast tRNA was added (lane $d$ ), no decrease in the complex band's intensity was observed. BSA $(5 \mu \mathrm{g})$ did not replace the r-protein mixture (lane $e$ ). Labeled sensestrand RNA probe (lane $f$ ) and a more 3' segment of human RPS14 intron 1 antisense RNA probe (lane $g$ ) did not bind to the r-protein. (B) Antiserum directed against r-protein S14 binds to the r-protein-antisense RNA binary complex. (Lane $a$ ) same as in $A$. Uniformly labeled pGA7 antisense RNA was incubated with the r-protein mixture for $15 \mathrm{~min}$ and then postincubated with $10 \mu \mathrm{l}$ of anti-human r-protein S14 serum (lane $b$ ) or preimmune control serum (lane $e$ ) for 10 min at $37^{\circ} \mathrm{C}$. In other reactions, the r-protein mixture was preincubated for $10 \mathrm{~min}$ with $10 \mu \mathrm{l}$ of anti-S14 serum (lane c) or $10 \mu \mathrm{l}$ of preimmune control serum (lane $d$ ) before addition of the radioactive S14 antisense RNA. (C) A deletion within the RPS14 intron 1 NF- $\beta 1$-binding site abolishes the antisense RNA-S14 protein interaction. ${ }^{32}$ P-labeled RNA probe transcribed from pG50 (lane $a$ ) or pG72, a clone that carries a 34-bp deletion surrounding the NF- $\beta$-binding site (lane $b$ ), was tested in the standard r-protein binding reaction. $(D)$ Recombinant GST-S14 fusion protein binds to S14 antisense RNA. Binding reactions contained ${ }^{32} \mathrm{P}-1$ labeled pGA7 antisense RNA and $30 \mu \mathrm{g}$ of either recombinant GST protein (lane $a$ ) or GST-S14 fusion protein (lane $b$ ). Indicated are the binary complex between S14 protein and antisense RNA (lower arrowhead) and the ternary complex between anti-S14 antibody, antisense RNA and S14 protein (upper arrowhead).

b) but not when the r-protein mixture was replaced by recombinant GST alone (lane a).

In a similar set of experiments, we also examined interactions between $\mathrm{S} 14$ protein and its own mRNA (Fig. 9). In these experiments, a ${ }^{32} \mathrm{P}$-labeled S14 mRNA probe was synthesized as a runoff transcript from an S14 cDNA cloned in pGEM-1. Data in Figure 9A indicated that a human $r$-protein binds to $S 14$ mRNA probe and produces a radioactive band with retarded electrophoretic mobility (lane a, arrow). As above, this binding reaction was both saturable and protein specific. Excess unlabeled S14 mRNA competitively displaced the radioactive probe
RNA (lanes b-d), but BSA did not substitute for the mixture of $r$-proteins in the binding reaction (lane e).

The mRNA sequence that bound the r-protein is located within the $5^{\prime}$-most 114 nucleotides of the S14 message (Fig. 9B). When mRNA probes were synthesized as runoff transcripts that terminated at the Bsu36I cleavage site in exon II (lane a) or at the AvaI site in exon IV (lane b), they bound the r-protein. However, when a radioactive probe lacking mRNA sequences $5^{\prime}$ of the exon II Bsu36I cleavage site was used, no r-protein was bound (lane c).

Data in Figure. 9, C and D, demonstrate that S14 is the
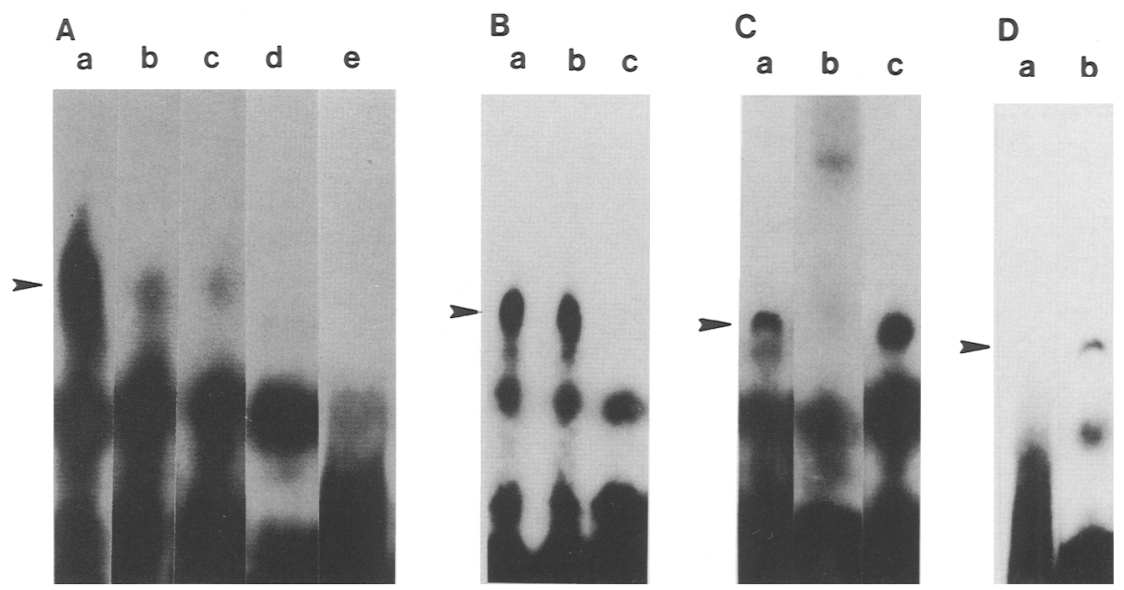

Figure 9. Human r-protein $\mathrm{S} 14$ binds specifically to a site near the $5^{\prime}$ end of its own mRNA. (A) Full-length, radioactive S14 mRNA probe was incubated with $30 \mu \mathrm{g}$ of a mixture of human r-proteins (lane a). $\mathrm{R}$-protein-binding reactions also were carried out in the presence of 10 (lane $b)-, 100$ (lane $c$ ), and 200 (lane $d$ )-fold excesses of nonradioactive competitor S14 mRNA. The binding reaction analyzed in lane $e$ contained BSA $(5 \mu \mathrm{g})$ instead of human r-proteins. (B) Truncated S14 mRNA probes were transcribed from pCS14-83 cut with Bsu36I (lane $a$ ) or Aval (lane b) or from pCS14-83A, which lacks RPS14 sequences upstream of the Bsu36I cleavage site in exon II. (C) Anti-S14 serum binds to the r-protein-S14 mRNA complex. Labeled full-length mRNA probe was preincubated with a mixture of human r-proteins (lane $a$ ) and postincubated with $10 \mu l$ of either anti-S14 antiserum (lane $b$ ) or preimmune serum (lane $c$ ) for $10 \mathrm{~min}$ at $37^{\circ} \mathrm{C}$. Other experimental details are described in the legend to Fig. 8 . 
r-protein that specifically binds the mRNA probes. AntiS14 serum bound and "super-shifted" the r-proteinmRNA complex (Fig. 9C, lane b, upper arrowhead). In the absence of antiserum (lane a) or in the presence of preimmunization control serum (lane c), only the mobility-shifted binary r-protein-mRNA complex was detected (lower arrow). In addition, recombinant GST-S14 fusion polypeptide formed a stable binary complex with S14 mRNA (Fig. 9D, lane b), whereas recombinant GST protein did not (lane a). Taken together, these data demonstrated that r-protein S14 specifically associates with an RNA sequence within 114 nucleotides of human S14 mRNA's 5' end.

\section{Discussion}

In this report we demonstrate that two overlapping antisense RNAs (250 and 280 nucleotides) are transcribed from the regulatory region of the human RPS14 gene's first intron in a variety of cultured human cells and differentiated tissues. Both RNAs appear to be primary transcripts, as there was no indication of longer precursor RNAs in vivo and the same two RNAs were detected among the products of a cell-free transcription reaction. Most of the 280-nucleotide antisense transcript (designated $\alpha-280)$ is localized in the nucleus of cultured human cells (HT1080), whereas all but a small fraction of the 250-nucleotide transcript $(\alpha-250)$ was found in the cells' cytoplasm. On the basis of its resistance to high concentrations of $\alpha$-amanitin, cell-free synthesis of $\alpha-250$ and $\alpha-280$ does not appear to involve mammalian RNA polymerase II. Rather, the reaction's resistance to $\alpha$-amanitin suggests that these antisense RNAs are transcribed by an $\alpha$-amanitin-resistant RNA polymerase, probably RNA polymerase I.

Transient expression and cell-free transcription experiments indicated that $\alpha-250 / \alpha-280$ stimulated biosynthesis of S14 mRNA. On this basis, the antisense RNAs appeared to be positive effectors of human RPS14 mRNA transcription. Although the mechanism by which the antisense RNAs stimulate RPS14 mRNA transcription is not known, $\alpha-250$ and $\alpha-280$ did not affect transcription from two other human r-protein loci $\{R P S 17$ and RPS24|. To our knowledge, this is the first report of locus-specific positive transcriptional regulation attributed to naturally occurring antisense RNAs. Mammalian antisense RNAs that negatively regulate housekeeping gene transcription have been described by others (Nepveu and Marcu 1986; Khochbin and Lawrence 1994).

Because expression of prokaryotic r-protein operons is fine-tuned by autoregulatory mechanisms that respond to r-protein effectors at the level of translation (Nomura et al. 1984), we used transient expression and the cellfree reaction to investigate the effects of $S 14$ protein on human RPS14 transcription. These experiments indicated that $\mathrm{S} 14$ protein inhibited biosynthesis of its own mRNA as well as $\alpha-250 / \alpha-280$ in a locus-specific manner. To investigate the molecular basis for these regulatory interactions, RNA-protein-binding studies were carried out. Experiments described herein demonstrate that $S 14$ protein specifically binds to its own mRNA and to $\alpha-250 / \alpha-280$. The site of protein binding within human S14 mRNA is within 114 nucleotides of the mRNA's $5^{\prime}$ end. This region of the mRNA includes the gene's noncoding first exon and the first 60 nucleotides of exon II.

A diagram summarizing the regulatory interactions described in this report is illustrated in Figure 10. As indicated, RPS14 intron 1 antisense RNAs $\{\alpha-250$ and $\alpha-280)$ stimulate transcription of S14 mRNA and therefore are depicted as positive regulators $(+)$ of the gene's expression. In contrast, S14 protein inhibits (-) its own mRNA's transcription at two levels: directly through a negative effect on the RPS14 mRNA transcription complex, and indirectly via inhibition of antisense RNA synthesis. This dual effect is particularly intriguing, because S14 mRNA is transcribed by mammalian RNA polymerase II, an $\alpha$-amanitin-sensitive enzyme, whereas the antisense RNAs are synthesized by an $\alpha$-amanitin-resistant enzyme, most likely RNA polymerase I. If $\alpha-250$ and $\alpha-280$ are transcribed by RNA polymerase I, the enzyme that transcribes rRNAs, then their stimulation of S14 mRNA synthesis provides a potentially useful "crossover site" for coregulation of r-protein and rRNA gene expression in mammalian cells.

Although the molecular basis for the regulatory effects of $\alpha-250, \alpha-280$, and $\mathrm{S} 14$ protein on transcription at the RPS14 locus remains to be determined, the effects observed in vitro and in cultured cells suggest that regulation involves binary molecular interactions among the antisense RNAs, S14 message, and the RPS14 transcription complex. Post-transcriptional models for $\alpha-250 / \alpha-$ 280 and S14 protein's regulatory effects, such as might involve differential mRNA processing or turnover, do

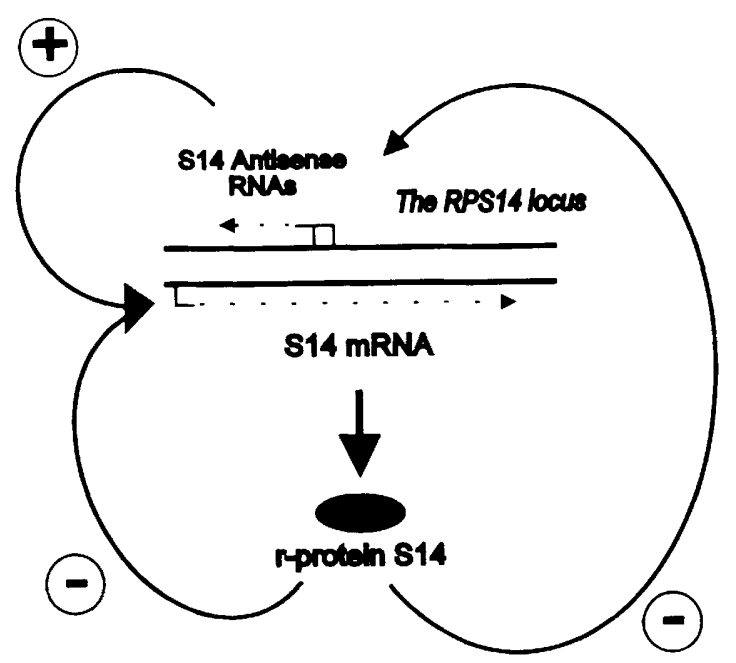

Figure 10. Antisense RPS14 intron 1 RNAs and S14 protein regulate transcription of S14 mRNA. Regulatory interactions described in this report are represented as arrows. $1+\mid$ Stimulatory (positive) regulation; $(-)$ inhibitory (negative) regulation. (See text for details). 
not account for the cell-free transcription data reported. Because the effects on transcription are locus-specific, the regulatory interactions are not likely to target RNA polymerase core components. Rather, they are more likely to involve locus-specific ancillary protein factors, such as E2F or NF- $\beta 1$ (Overman et al. 1993), which stimulate the RPS14 transcription or unusual template DNA structures within the S14 promoter itself. Interestingly, an imperfect 18-bp inverted repeat sequence is shared by the $5^{\prime}$ end of RPS14 exon I and the intron 1 regulatory region (Rhoads et al. 1986; Overman et al. 1993); and this motif is compatible with a relatively stable DNA cruciform structure.

The experiments described in this report pertain only to the human RPS14 locus and to its transcriptional regulation. However, we have detected short, $\alpha$-amanitinresistant antisense transcripts, similar to $\alpha-250$ and $\alpha-280$, within the regulatory introns of human RPS17 (Chen and Roufa 1988) and RPS24 (W.B. Xu and D.J. Roufa, in prep.), and in Chinese hamster cell RPS14 intron 1 (Rhoads and Roufa 1991). These findings imply that antisense RNA regulation also might fine-tune transcription of other mammalian r-protein messages.

\section{Materials and methods}

Materials

Total cell RNAs from several human tissues were generously supplied by Clontech Laboratories, Inc. (Palo Alto, CA). The pGEM-T vector was purchased from Promega Corp. Lipofectamine was obtained from GIBCO BRL Life Technologies, and $\alpha$-amanitin from Bochringer Mannheim Corp. A recombinant clone encoding GST-S14 fusion polypeptide was constructed in the plasmid expression vector pGEX-2T (Pharmacia BioTech, Inc.). This plasmid was grown in Escherichia coli $\mathrm{HB101}$, and the fusion polypeptide was purified to electrophoretic homogeneity by glutathione-Sepharose chromatography (X.G. Leng and D.J. Roufa, unpubl.). A polyclonal antiserum directed against a synthetic 15 -amino-acid peptide modeled after the carboxyl terminus of human S14 (PSDSTRRKGGRRGRR) was prepared in white New Zealand rabbits (Krishnamachary et al. 1994). Commercial sources for the other enzymes and reagents used in this study have been described before (Tasheva and Roufa 1993, 1994a,b).

\section{Human RPS14, RPS17, and RPS24 DNA clones and RNA probes}

The human RPS14 DNA sequence is listed in the GenBank data base under accession number M13934. All references to the gene's nucleotide sequence are indexed according to the numbering system specified in GenBank. The recombinant bacteriophage $\lambda$ clone HGS14-1 contains $12.5 \mathrm{~kb}$ of human genomic DNA that codes for the RPS14 locus (Rhoads et al. 1986). A minimal pUC13 expression clone of human RPS14, pCS14-83, includes $32 \mathrm{bp}$ of upstream chromosomal sequence, exon I, intron 1 and exons II-V derived from an S14 cDNA (Overman et al. 1993). The clone, pCS14-93, contains a full-length $D$. melanogaster S14 cDNA under transcriptional control of the SV40 early gene promoter (Maki et al. 1990). pCS17-92 is a functional plasmid clone of the human r-protein S17 locus (Chen and Roufa 1988). Recombinant S14 plasmid clones assembled specifi- cally for this study (Fig. 1A) were constructed from HGS14-1 and pCS14-83 as follows.

The BspMI-PflMI DNA fragment of HGS14-1, containing most of the RPS14 intron 1, was cloned into the SmaI site of pGEM-1 (Promega Corp.). This yielded plasmids pGA4 and pGA7 (Fig. 1A), whose DNA inserts are in opposite orientations with respect to the vector's polylinker and transcriptional promoters. S14 sense-strand RNAs were transcribed from pGA4 with T7 RNA polymerase as runoff RNAs terminating either at the polylinker HindIII site or the RPS14 intron $1 \mathrm{NcoI}$ cleavage site. S14 antisense RNAs were transcribed by T7 RNA polymerase from pGA7 template cleaved with HindIII. The NarI-Bsu36I DNA fragment, encoding $\sim 1 \mathrm{~kb}$ of upstream chromosomal DNA, RPS14 exon I, intron 1, and 60 bp of exon II was introduced into the SmaI site of pGEM-1 to produce pGANB (Fig. 1A). S14 mRNAs were transcribed from pGANB template cut at the polylinker HindIII site with T7 RNA polymerase. The same DNA fragment also was inserted between the HindIII and SmaI sites of pSV2Neo to produce pSVAS (Fig. 1A), where it was placed under transcriptional control of both its own promoter and the SV40 early gene promoter.

A 290-bp DNA fragment derived from the $5^{\prime}$ end of RPS14's first intron was synthesized by PCR amplification from plasmid pGA4. The primers used were 5'-ACCTGTGGGGCTTGGGACGAGAGACGGG-3' (nucleotides 301-328) and 5'-GTTTGGCGAGGTAGAGCGGGAGCCCACG-3' (nucleotides 590563). The DNA fragment amplified was cloned into pGEM-T to yield pGTOI (Fig. 1A). Sense and antisense RNAs were transcribed with SP6 and T7 RNA polymerases as runoff products to the pGTOI NcoI and PstI cleavage sites, respectively. pCS14$80 \mathrm{~A}$ was derived from pCS14-83 (see above) by excising the S14 sequence between the vector polylinker HindIII site and exon II Bsu36I sites. Thus, pCS14-80A encodes an S14 mRNA that lacks exon I and the first $60 \mathrm{bp}$ of exon II. The EcoRI-BamHI fragment of pCS14-83, containing 32 bp of upstream DNA and the first $187 \mathrm{bp}$ of RPS14 (exon I plus $132 \mathrm{bp}$ of intron 1), was cloned between the EcoRI and BamHI sites of pGEM-l to produce plasmid pG50 (Fig. 1A). The analogous DNA fragment of a mutant clone pCS14-144 (Overman et al. 1993), from which 34 bp of intron 1 was deleted (between positions 328 and 361, Fig. lB), also was inserted into pGEM-1 to yield plasmid pG72 (Fig. 1A). The structures and orientations of all DNA constructs were verified by detailed restriction maps and analysis of critical DNA sequences.

SP6 and T7 transcription reactions were performed as described (Maki et al. 1990). RNAs were labeled with $50 \mu \mathrm{M}$ $\left[\alpha^{-32}\right.$ P]rUTP (DuPont-NEN Research Products) at a specific radioactivity of $2 \times 10^{4} \mathrm{mCi} / \mathrm{mMole}$. rATP, rCTP and rGTP were added to the reactions at $500 \mu \mathrm{M}$. Following synthesis, template DNAs were digested with RQ1 ribonuclease-free DNase I (Promega Corp.) at $37^{\circ} \mathrm{C}$ for $30 \mathrm{~min}$. Amounts of labeled RNAs were estimated from the ${ }^{32} \mathrm{P}$ incorporated. Concentrations of nonradioactive RNAs were determined spectrophotometrically, and the integrity of all RNA transcripts was examined by agarose gel electrophoresis.

\section{Cell culture, transient expression, and RNase protection assays}

HT1080 (ATCC No. CCL 121) and HeLa S3 (ATCC no. CCL 2.2) cells were maintained in Dulbecco's modified Eagle minimal medium supplemented with $10 \%$ fetal calf serum (FCS). CCRFCEM cells (ATCC CCL 119) and HL-60 cells (ATCC CCL240) were grown in RPMI 1640 medium plus $10 \%$ FCS. One million HT1080 cells were transfected with $10 \mu \mathrm{g}$ of plasmid DNA (pSVAS or pCS14-93) using lipofectamine according to the 
method recommended by the manufacturer. This protocol routinely resulted in transfection frequencies of $80-90 \%$, as judged by transient expression of cloned genes (M. Pyle and D.J. Roufa, unpubl.). Twenty-four hours later, total cellular or cytoplasmic and nuclear RNAs were prepared as described previously (Chomczynski and Sacchi 1987; Maki et al. 1990; Overman et al. 1993).

For RNase protection assays, ${ }^{32} \mathrm{P}$-labeled RNA probe $\left(1 \times 10^{6}\right.$ $\mathrm{cpm}$ ) and $10 \mu \mathrm{g}$ of the RNA sample were dried under vacuum. After redissolving the dried samples in $30 \mu \mathrm{l}$ of $80 \%$ formamide, $40 \mathrm{~mm}$ PIPES, $400 \mathrm{~mm} \mathrm{NaCl}$, and $1 \mathrm{~mm}$ EDTA (pH 6.4), the hybridizations were then carried out overnight (12-14 hr) at $60^{\circ} \mathrm{C}$. Nonhybridized probes were digested with RNase A 150 $\mu \mathrm{g} / \mathrm{ml})$ and RNase Tl (5 units/ml), as described by Zinn et al. (1983). Nuclease-resistant riboprobe fragments were resolved by electrophoresis through denaturing $8 \%$ polyacrylamide gels, visualized by autoradiography, and analyzed quantitatively by soft laser densitometry.

\section{Cell-free transcription of cloned human r-protein gene fragments}

Nuclear extracts were prepared from mid-log phase HeLa cells as described (Dignam et al. 1983; Overman et al. 1993). Cell-free transcription was carried out in $25-\mu \mathrm{l}$ reaction mixtures that contained $25 \mathrm{~mm}$ HEPES (pH 7.9), $1 \mathrm{~mm}$ dithiothreitol, $6 \mathrm{~mm}$ $\mathrm{MgCl}_{2}, 9 \%$ (vol/vol) glycerol, $100 \mathrm{mM} \mathrm{KCl}, 600 \mu \mathrm{M}$ of each rNTP, a cloned duplex DNA template $(500 \mathrm{ng})$, and nuclear extract $(12 \mu \mathrm{l})$. After $45 \mathrm{~min}$ incubation at $30^{\circ} \mathrm{C}$, reaction mixtures were digested with RQ1 RNase-free DNase I. RNA reaction products were precipitated in ethanol and prepared for nuclease protection analysis, as detailed above.

\section{$R N A$ /protein-binding assays}

Human r-proteins were extracted from purified HeLa cell ribosomes (Boersma et al. 1979; Madjar et al. 1982). RNA/proteinbinding reactions and EMSAs followed methods developed by others (Leibold and Munro 198 8; Chu et al. 1993). Each 20- $\mu$ l RNA-binding reaction contained $1 \mathrm{ng}$ of ${ }^{32} \mathrm{p}$-labeled RNA probe $(10,000 \mathrm{cpm})$ and $25 \mu \mathrm{g}$ of purified HeLa cell $\mathrm{r}$-proteins. After 15 min incubation at $22^{\circ} \mathrm{C}$, samples were digested with RNase T1, treated with heparin, and resolved by electrophoresis on neutral $4 \%$ polyacrylamide gels (Leibold and Munro 1988). Electrophoresis gels were dried in vacuo and analyzed by autoradiography using Cronex Lightening Plus intensifying screens.

\section{Acknowledgments}

We are grateful to Mrs. Andrea Fernandez and Mr. Ralph Najarian for their expert technical assistance. We also acknowledge Drs. M. Li and M.S. Center for their help in synthesizing the r-protein S14 peptide immunogen and Dr. X.G. Leng for preparation of the GST-S14 fusion polypeptide. This research was supported by a grant from the National Institute of General Medical Science (GM23013). E.S.T. is a postdoctoral cancer research fellow of the Kansas Health Foundation (Wichita). This publication is contribution no. 95-171-J from the Kansas Agricultural Experiment Station.

The publication costs of this article were defrayed in part by payment of page charges. This article must therefore be hereby marked "advertisement" in accordance with 18 USC section 1734 solely to indicate this fact.

\section{References}

Agrawal, M.G. and L.H. Bowman. 1987. Transcriptional and translational regulation of ribosomal protein formation during mouse myoblast differentiation. I. Biol. Chem. 262: 4868-4875.

Aloni, R., D. Peleg, and O. Meyuhas. 1992. Selective translational control and nonspecific posttranscriptional regulation of ribosomal protein gene expression during development and regeneration of rat liver. Mol. Cell. Biol. 12: 2203-2212.

Belhumeur, P., M. Lussier, and D. Skup. 1988. Expression of naturally occurring RNA molecules complementary to the murine L27' ribosomal protein mRNA. Gene 72: 277-285.

Boersma, D., S.M. McGill, J.W. Mollenkamp, and D.J. Roufa. 1979. Emetine resistance in Chinese hamster cells. Analysis of ribosomal proteins prepared from mutant cells. I. Biol. Chem. 254: 559-567.

Chen, I.-T. and D.J. Roufa. 1988. The transcriptionally active human ribosomal protein S17 gene. Gene 70: 107-116.

Chomczynski, P. and N. Sacchi. 1987. Single step method of RNA isolation by acid guanidinium thiocyanate-phenolchloroform extraction. Anal. Biochem. 162: 156-159.

Chu, E., D. Voeller, D.M. Koeller, J.C. Drake, C.H. Takimoto, G.F. Maley, F. Maley, and C.J. Allegra. 1993. Identification of an RNA binding site for human thymidylate synthase. Proc. Natl. Acad. Sci. 90: 517-523.

Cole, J.R. and M. Nomura. 1986. Translational regulation is responsible for growth-rate-dependent and stringent control of the synthesis of ribosomal proteins $\mathrm{L} 1 \mathrm{l}$ and $\mathrm{Ll}$ in Escherichia coli. Proc. Natl. Acad. Sci. 83: 4129-4133.

Dabeva, M.D. and J.R. Warner. 1993. Ribosomal protein L32 of Saccharomyces cerevisiae regulates both splicing and translation of its own transcript. I. Biol. Chem. 268: 1966919674.

Della Sita, F., S.-A. Ciafre, C. Marck, B. Santoro, C. Presutti, A. Sentenac, and I. Bozzoni. 1990. The ABFl factor is the transcriptional activator of the L2 ribosomal protein genes in Saccharomyces cerevisiae. Mol. Cell. Biol. 10: 2437-2441.

Diaz, J.-J. and D.J. Roufa. 1992. Fine structure map of the human ribosomal protein gene RPS14. Mol. Cell. Biol. 12: 16801686.

Diaz, J.-J., D.D. Rhoads, and D.J. Roufa. 1990. Genetic analysis of a vital mammalian housekeeping locus using $\mathrm{CHO}$ cells that express a transfected mutant allele. Somat. Cell Mol. Genet. 16: 517-528.

Dignam, J.D., R.M. Lebovitz, and R.G. Roeder. 1983. Accurate transcription by RNA polymerase II in a soluble extract from isolated mammalian nuclei. Nucleic Acids Res. 11: 14751489.

Fallon, A.M., C.S. Jinks, G.D. Strycharz, and M. Nomura. 1979. Regulation of ribosomal protein synthesis in Escherichia coli by selective mRNA inactivation. Proc. Natl. Acad. Sci. 76: 3411-3415.

Ferrari, S., R. Manfredini, E. Tagliafico, E. Rossi, A. Donelli, G. Torelli, and U. Torelli. 1990. Noncoordinated expression of S6, S11, and S14 ribosomal protein genes in leukemic blast cells. Cancer Res. 50: 5825-5828.

Gibbs, R.A. and C.T. Caskey. 1987. Identification and localization of mutations at the Lesch-Nyhan locus by ribonuclease A cleavage. Science 236: 303-305.

Gorenstein, C. and J.R. Warner. 1976. Coordinate regulation of the synthesis of eukaryotic ribosomal proteins. Proc. Natl. Acad. Sci. 73: 1547-1551. 
Hammond, M.L. and L.H. Bowman. 1988. Insulin stimulates the translation of ribosomal proteins and the transcription of rDNA in mouse myoblasts. I. Biol. Chem. 263: 1778517791.

Henry, J.L., D.L. Coggin, and C.R. King. 1993. High-level expression of the ribosomal protein L19 in human breast tumors that overexpress erbB-2. Cancer Res. 53: 1403-1408.

Hildebrandt, M. and W. Nellen. 1992. Differential antisense transcription from the Dictyostelium EB4 gene locus: Implications on antisense-mediated regulation of mRNA stability. Cell 69: 197-204.

Kearney, K.R. and M. Nomura. 1987. Secondary structure of the autoregulatory mRNA binding site of ribosomal protein L1. Mol. Gen. Genet. 210: 60-68.

Khochbin, S. and J.-J. Lawrence. 1994. An antisense RNA involved in p53 mRNA maturation in murine erythroleukemia cells induced to differentiate. EMBO I. 8: 4107-4114.

Kief, D.R. and J.R. Warner. 1981. Coordinate control of syntheses of ribosomal ribonucleic acid and ribosomal proteins during nutritional shift-up in Saccharomyces cerevisiae. Mol. Cell. Biol. 1: 1007-1015.

Kimelman, D. and M.W. Kirshner. 1989. An antisense mRNA directs the covalent modification of the transcript encoding fibroblast growth factor in Xenopus oocytes. Cell 59: 687696.

Krishnamachary, N., L. Ma, L. Zheng, A.R. Safa, and M.S. Center. 1994. Analysis of MRP gene expression and function in HL60 cells isolated for resistance to adriamycin. Oncol. Res. 6: 119-127.

Krystal, G.W., B.C. Armstrong, and J.F. Battey. 1990. N-myc mRNA forms an RNA-RNA duplex with endogenous antisense transcripts. Mol. Cell. Biol. 10: 4180-4191.

Laine, R.O., P.J. Laipis, N.F. Shay, and M.S. Kilberg. 1991. Identification of an amino acid-regulated mRNA from rat liver as the mammalian equivalent of bacterial ribosomal protein L22. I. Biol. Chem. 266: 16969-16972.

Leibold, E.A. and H.N. Munro. 1988. Cytoplasmic protein binds in vitro to a highly conserved sequence in the 5 ' untranslated region of ferritin heavy- and light-subunit mRNAs. Proc. Natl. Acad. Sci. 85: 2171-2175.

Levy, S., D. Avni, N. Hariharan, R.P. Perry, and O. Meyuhas. 1991. Oligopyrimidine tract at the 5 ' end of mammalian ribosomal protein mRNAs is required for their translational control. Proc. Natl. Acad. Sci. 88: 3319-3323.

Li, M. and M.S. Center. 1992. Regulation of ribosomal protein S25 in HL60 cells isolated for resistance to adriamycin. FEBS Lett. 298: 142-144.

Lindahl, L. and J.M. Zengel. 1990. Autogenous control is not sufficient to ensure steady-state growth rate-dependent regulation of the S10 ribosomal protein operon of Escherichia coli. I. Bacteriol. 172: 305-309.

Lindahl, L., F. Sor, R.H. Archer, M. Nomura, and J.M. Zengel. 1990. Transcriptional organization of the $S 10$, spc and $\alpha$ operons of Escherichia coli. Biochim. Biophys. Acta Gene Struct. Expression 1050: 337-342.

Mackie, G.A. 1991. Specific endonucleolytic cleavage of the mRNA for ribosomal protein S20 of Escherichia coli requires the product of the ams gene in vivo and in vitro. 1. Bacteriol. 173: 2488-2497.

Madjar, J.-J., K. Nielsen-Smith, M. Frahm, and D.J. Roufa. 1982. Emetine resistance in Chinese hamster ovary cells is associated with an altered ribosomal protein S14 mRNA. Proc. Natl. Acad. Sci. 79: 1003-1007.

Madjar, J.-J., M. Frahm, S.M. McGill, and D.J. Roufa. 1983. Ribosomal protein S14 is altered by two-step emetine resistance mutations in Chinese hamster cells. Mol. Cell. Biol.
3: 190-197.

Mager, W.H. and R.J. Planta. 1990. Multifunctional DNA-binding proteins mediate concerted transcription activation of yeast ribosomal protein genes. Biochim. Biophys. Acta Gene Struct. Expression 1050: 351-355.

__ 1991. Coordinate expression of ribosomal protein genes in yeast as a function of cellular growth rate. Mol. Cell. Biochem. 104: 181-187.

Mailhammer, R., H. Szöts, J. Bönisch, and P. Dörmer. 1992. Down regulation of messenger RNA levels for ribosomal proteins in differentiating HL-60 cells. Exp. Cell Res. 200: 145-148.

Maki, C.G., D.D. Rhoads, J.-J. Diaz, and D.J. Roufa. 1990. A Drosophila ribosomal protein functions in mammalian cells. Mol. Cell. Biol. 10: 4524-4528.

Mattheakis, L., L. Vu, F. Sor, and M. Nomura. 1989. Retroregulation of the synthesis of ribosomal proteins L14 and L24 by feedback repressor S8 in Escherichia coli. Proc. Natl. Acad. Sci. 86: 448-452.

Meyuhas, O., E.A. Thompson Jr., and R.P. Perry. 1987. Glucocorticoids selectively inhibit translation of ribosomal protein mRNAs in p1798 lymphosarcoma cells. Mol. Cell. Biol. 7: 2691-2699.

Moehle, C.M. and A.G. Hinnebusch. 1991. Association of RAP1 binding sites with stringent control of ribosomal protein gene transcription in Saccharomyces cerevisiae. Mol. Cell. Biol. 11: 2723-2735.

Nepveu, A. and K.B. Marcu. 1986. Intragenic pausing and antisense transcription within the murine c-myc locus. $E M B O$ f. 5: 2859-2865.

Nomura, M., J.L. Yates, D. Dean, and L.E. Post. 1980. Feedback regulation of ribosomal protein gene expression in Escherichia coli: Structural homology of ribosomal RNA and ribosomal protein mRNA. Proc. Natl. Acad. Sci. 77. 70847088.

Nomura, M., R. Gourse, and G. Baughman. 1984. Regulation of the synthesis of ribosomes and ribosomal components. Annu. Rev. Biochem. 53: 75-118.

Overman, P.F., D.D. Rhoads, E.S. Tasheva, M.M. Pyle, and D.J. Roufa. 1993. Multiple regulatory elements ensure accurate expression of a human ribosomal protein gene. Somat. Cell Mol. Genet. 19: 347-362.

Papciak, S.M. and N.J. Pearson. 1992. The role of promoter elements of a ribosomal protein gene in Saccharomyces cerevisiae under various physiological conditions. Mol. \& Gen. Genet. 234: 22-32.

Pearson, N.J., H.M. Fried, and J.R. Warner. 1982. Yeast use translational control to compensate for extra copies of a ribosomal protein gene. Cell 29: 347-355.

Perry, R.P. and O. Meyuhas. 1990. Translational control of ribosomal protein production in mammalian cells. Enzyme 44: 83-92.

Petersen, C. 1990. Escherichia coli ribosomal protein L10 is rapidly degraded when synthesized in excess of ribosomal protein L7/L12. J. Bacteriol. 172: 431-436.

Pogue-Geile, K., J.R. Geiser, M. Shu, C. Miller, I.G. Wool, A.I. Meisler, and J.M. Pipas. 1991. Ribosomal protein genes are overexpressed in colorectal cancer: Isolation of a cDNA clone encoding the human S3 ribosomal protein. Mol. Cell. Biol. 11: 3842-3849.

Portier, C., C. Philippe, L. Dondon, M. Grunberg-Manago, J.P. Ebel, B. Ehresmann, and C. Ehresmann. 1990. Translational control of ribosomal protein S15. Biochim. Biophys. Acta Gene Struct. Expression 1050: 328-336.

Presutti, C., S.-A. Ciafré, and I. Bozzoni. 1991. The ribosomal protein L2 in S. cerevisiae controls the level of accumulation 
of its own mRNA. EMBO $f$. 10: 2215-2221.

Prislei, S., A. Michienzi, C. Presutti, P. Fragapane, and I. Bozzoni. 1993. Two different snoRNAs are encoded in introns of amphibian and human $\mathrm{Ll}$ ribosomal protein genes. Nucleic Acids Res. 21: 5824-5830.

Rhoads, D.D. and D.J. Roufa. 1987. A cloned human ribosomal protein gene functions in rodent cells. Mol. Cell. Biol. 7: 3767-3774.

. 1991. Molecular evolution of the mammalian ribosomal protein gene, RPS14. Mol. Biol. Evol. 8: 503-514.

Rhoads, D.D., A. Dixit, and D.J. Roufa. 1986. Primary structure of human ribosomal protein $\mathrm{S} 14$ and the gene that encodes it. Mol. Cell. Biol. 6: 2774-2783.

Singer, P. and M. Nomura. 1985. Stability of ribosomal protein mRNA and translational feedback regulation in Escherichia coli. Mol. \& Gen. Genet. 199: 543-546.

Skouv, I., J. Schnier, M.D. Rasmussen, A.R. Subramanian, and S. Pedersen. 1990. Ribosomal protein S1 of Escherichia coli is the effector for the regulation of its own synthesis. $J$. Biol. Chem. 265: 17044-17049.

Southern, P.J. and P. Berg. 1982. Transformation of mammalian cells to antibiotic resistance with a bacterial gene under control of the sv40 early region promoter. I. Mol. Applied Genet. 1: 327-341.

Spicer, D.B. and G.E. Sonenshein. 1992. An antisense promoter of the murine c-myc gene is localized within intron 2. Mol. Cell. Biol. 12: 1324-1329.

Tasheva, E.S. and D.J. Roufa. 1993. Deoxycytidine methylation and the origin of spontaneous transition mutations in mammalian cells. Somat. Cell Mol. Genet. 19: 275-283.

1994a. A mammalian origin of bidirectional DNA replication within the transcribed sequences of the Chinese hamster ribosomal protein S14 locus. Mol. Cell. Biol. 14: $5628-5635$.

1994b. Densely methylated DNA islands in mammalian chromosomal replication origins. Mol. Cell. Biol. 14: 56365644.

Thomas, M.S., D.M. Bedwell, and M. Nomura. 1987. Regulation of alpha operon gene expression in Escherichia coli, a novel form of translational coupling. I. Mol. Biol. 196: 333-345.

Tycowski, K.T., M.-D. Shu, and J.A. Steitz. 1993. A small nucleolar RNA is processed from an intron of the human gene encoding ribosomal protein S3. Genes \& Dev. 7: 1176-1 190.

Warner, J.R., G. Mitra, W.F. Schwindinger, M. Studeny, and H.M. Fried. 1985. Saccharomyces cerevisiae coordinates accumulation of yeast ribosomal proteins by modulating mRNA splicing, translational initiation and protein turnover. Mol. Cell. Biol. 5: 1512-1521.

Wikström, P.M., L.K. Lind, D.E. Berg, and G.R. Björk. 1992. Importance of mRNA folding and start codon accessibility in the expression of genes in a ribosomal protein operon of Escherichia coli. J. Mol. Biol. 224: 949-966.

Yates, J.L. and M. Nomura. 1980. E. coli ribosomal protein L4 is a feedback regulatory protein. Cell 21:517-522.

Yates, J.L., A.E. Arfsten, and M. Nomura. 1980. In vitro expression of Escherichia coli ribosomal protein genes: Autogenous inhibition of translation. Proc. Natl. Acad. Sci. 77: 1837-1841.

Zengel, J.M. and L. Lindahl. 1990. Escherichia coli ribosomal protein $\mathrm{L} 4$ stimulates transcription termination at a specific site in the leader of the S10 operon independent of L4-mediated inhibition of translation. J. Mol. Biol. 213: 67-78.

Zinn, K., D. Dimaio, and T. Maniatis. 1983. Identification of two distinct regulatory regions adjacent to the human betainterferon gene. Cell 34: 865-879. 


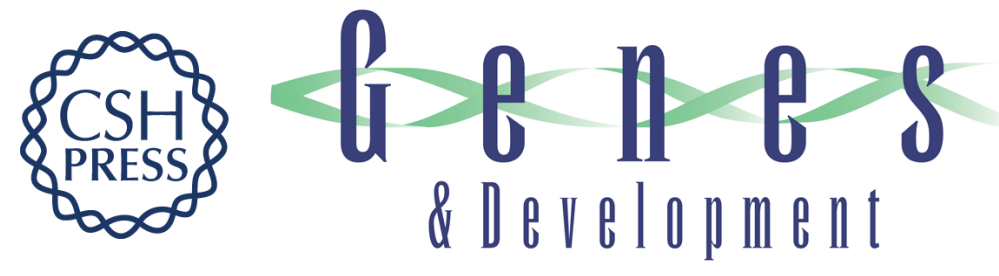

\section{Regulation of human RPS14 transcription by intronic antisense RNAs and ribosomal protein S14.}

E S Tasheva and D J Roufa

Genes Dev. 1995, 9:

Access the most recent version at doi:10.1101/gad.9.3.304

References This article cites 72 articles, 39 of which can be accessed free at:

http://genesdev.cshlp.org/content/9/3/304.full.html\#ref-list-1

License

Email Alerting

Service

Receive free email alerts when new articles cite this article - sign up in the box at the top right corner of the article or click here.

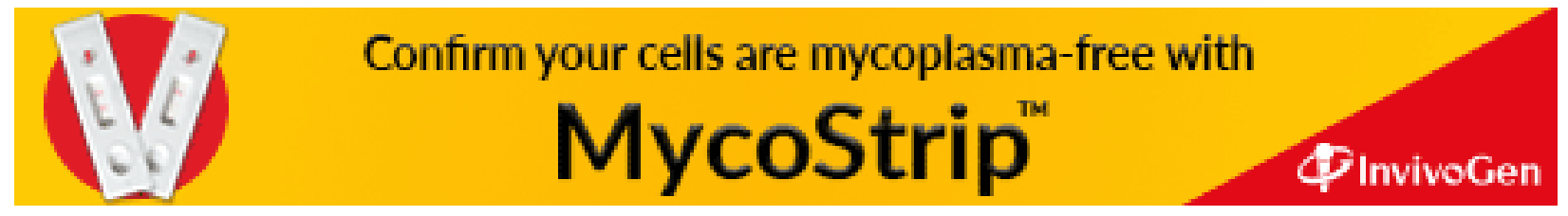

